\title{
ENERGY EXPENDITURE OF AMBULATION IN PARAPLEGICS: EFFECTS OF LONG TERM USE OF BRACING*
}

\author{
By A. Chantraine, M.D., ${ }^{1}$ J. M. Crielaard, M.D., ${ }^{2}$ A. Onkelinx, M.D. ${ }^{2}$ \\ and F. PIRNAY, M.D. ${ }^{3}$ \\ ${ }^{1}$ Service of Physical Medicine and Rehabilitation, Hôpital Cantonal Universitaire, \\ Geneva, Switzerland. ${ }^{2}$ Service of Physical Medicine and Rehabilitation, (Prof. \\ Franchimont), Hôpital Universitaire de Liège, Belgium. ${ }^{3}$ Service of Sport Physiology, \\ Institut E. Malvoz, Université de Liège (Prof. Petit), Belgium.
}

Summary. Energy metabolism data were collected in a series of seven male paraplegic patients with complete spinal cord lesions ( $\mathrm{T}_{9}$ to $\mathrm{L}_{\mathrm{I}}$ ). Among these four had just been rehabilitated and three had been using their bilateral long leg braces for more than 4 years. A group of five healthy volunteers was used as a control. All the subjects ambulated on a treadmill between parallel bars and in a second trial they ambulated on the floor using forearm crutches.

Mean $\mathrm{O}_{2}$ consumption was $\mathrm{I} \cdot 46 \mathrm{ml} \mathrm{O} / \mathrm{kg} / \mathrm{m}$ for the unaccustomed paraplegics who had never used long-leg braces before, $0.6 \mathrm{I}$ for paraplegics used to walking with braces, and 0.83 for the healthy subjects walking between parallel bars with a swing-through gait.

The second trial (on the floor), showed a mean $\mathrm{O}_{2}$ consumption of $0.73 \mathrm{ml}$ $\mathrm{O}_{2} / \mathrm{kg} / \mathrm{m}$ for the paraplegic brace-user with a high heart rate (I $56 / \mathrm{min}$.). This mean $\mathrm{O}_{2}$ consumption was much lower than the values of the paraplegic non-user and slightly higher than the normal subjects.

Key words: Spinal cord injury; Energy metabolism; Effects of physical training; Bracing.

\section{Introduction}

WHILE teaching a paraplegic patient how to walk with bracing, problems may arise not only involving the appliances but also the muscular adaptation above the lesion. Indeed, considerable muscular work of the upper limbs and trunk above the paralysis is required during walking with bilateral long leg braces (Chantraine and Onkelinx, I975) this having repercussions on the entire cardiopulmonary system (Huang et al., 1979). Several works have already been published concerning the energy utilization during walking in normal subjects or with those having a motor handicap such as an amputation, hemiplegia, paraplegia or a fracture of the lower limb (Bard, I963; Clinkingbeard et al., I964; Salmon and Chantraine, I972; Ganguli et al., I 973 and I974; James, I973; Imms et al., I976; Fischer and Gullickson, I978; Huang et al., I979; Veicsteinas et al., 1979). Nevertheless, none of these studies were made over a long period of time. The problem of walking was always investigated during a particular physical situation, at a precise time in the rehabilitation or following a training period of several months.

Reprints: Professor A. Chantraine, M.D., Ph.D., Department of Physical Medicine and Rehabilitation, Hôpital Cantonal Universitaire, CH 12 I I Geneva 4.

$\star$ This paper was read at the Athens I.M.S.P. Meeting, October, I982. 
It appeared worthwhile to compare the energy metabolism of a paraplegic with bracing during the time that he is learning to walk, to that which is recorded after the orthosis is used for several years. It seemed interesting to analyse the various possibilities that play an important role in a paraplegic becoming accustomed to using an appliance over a long period of time and the eventual changes in physiological expenditure that this might cause.

\section{Observations and Methods}

Seven male paraplegic patients with complete lesions from $\mathrm{T}_{9}$ to $\mathrm{L}_{\mathrm{I}}$ were examined. They were subdivided into two groups as shown in Table I.

In the first group (unaccustomed paraplegics: UAP), composed of four subjects from i 8 to 4 I years of age, three were given a simple explanation and demonstration of how to walk with long-leg braces after a maximum hospitalisation of 7 months. The fourth patient ( 20 years old), was paraplegic for 20 months and practically did not use his walking orthosis. The second group (accustomed paraplegics: AP), was comprised of three subjects from 24 to 29 years of age who were paraplegic for more than 4 years and who used their long leg braces regularly. Simultaneously five healthy normal male volunteers 26 to 48 years old, made up our control group and were studied in a similar manner.

Each individual, prior to beginning the programme, underwent a medical examination with particular attention to the pulmonary and cardiovascular systems. Each subject (before the actual trial), was allowed to walk on the treadmill and breathe in the Douglas bag for a preliminary trial of 2 minutes in order to accustom himself to the procedure. This was done at varying speeds which were sufficiently slow for this type of ambulation, and allowed the subject to choose the actual speed at which the trial was to be carried out.

TABLE I

\begin{tabular}{|c|c|c|c|c|c|}
\hline No. & Subjects & Age & Level & $\begin{array}{l}\text { Time of paraplegia } \\
\text { (in months) }\end{array}$ & $\begin{array}{l}\text { Weight } \\
\text { (in } \mathrm{kg} \text { ) }\end{array}$ \\
\hline \multicolumn{6}{|c|}{ U.A.P. ${ }^{\star}$} \\
\hline I & C.A. & I 8 & TI 2 & 3 & $6 I$ \\
\hline 2 & S.R. & 29 & $\mathrm{~T} 9$ & 7 & 76 \\
\hline 3 & D.F. & $4 I$ & L I & 7 & $7 \mathrm{I}$ \\
\hline 4 & M.V. & 20 & TI2 & 20 & 71 \\
\hline \multicolumn{6}{|c|}{ 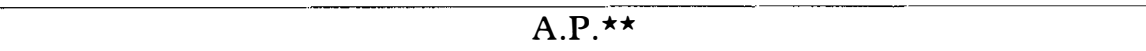 } \\
\hline 5 & J.M. & 24 & Tio & 48 & 67 \\
\hline 6 & C.P.A. & 29 & TII & 66 & 80 \\
\hline 7 & L.P. & 26 & TII & 54 & 74 \\
\hline \multicolumn{6}{|c|}{ Normal subjects } \\
\hline 8 & W.G. & 26 & & & 72 \\
\hline 9 & S.A. & 38 & & & 75 \\
\hline IO & V.J. & 35 & & & 48 \\
\hline I I & J.M.C. & 29 & & & 72 \\
\hline I 2 & F.P. & 48 & & & 70 \\
\hline
\end{tabular}

$\star$ Paraplegic unaccustomed to long-leg brace use

$\star \star$ Paraplegic accustomed to long-leg brace use 
This preliminary trial was carried out on the same day or the day preceding the actual trial, allowing in every case at least several hours between this preliminary trial and the actual recording. Then all of the subjects were examined once while walking on a treadmill with a simultaneous bipedal weight-bearing and swing-through gait (Fig. I). Two bars, whose height could be adjusted, were placed on each side of the treadmill and were used as hand supports during pendular, swing-through walking. The real forward speed was calculated from the number of swing-through movements per minute and the length of the step. These displacement exercises, equivalent to pendular walking, are performed only with the help of the upper limbs.

The five nonparalysed subjects performed the same pendular walking exercise. Each subject was allowed to dictate the speed which allowed him to ambulate comfortably. This speed, as can be read from Table II and converted into $\mathrm{km} / \mathrm{h}$, was $0.5-\mathrm{I} \cdot 0 \mathrm{~km} / \mathrm{h}$ for the unaccustomed paraplegics, $\mathrm{I} \cdot 2 \mathrm{~km} / \mathrm{h}$ for the accustomed paraplegics, and $2.3 \mathrm{~km} / \mathrm{h}$ for the healthy control subjects. The various cardio-pulmonary parameters were measured over a period of 2 minutes, which represents the time span for each individual tested (after an initial warm-up period of about I minute). The

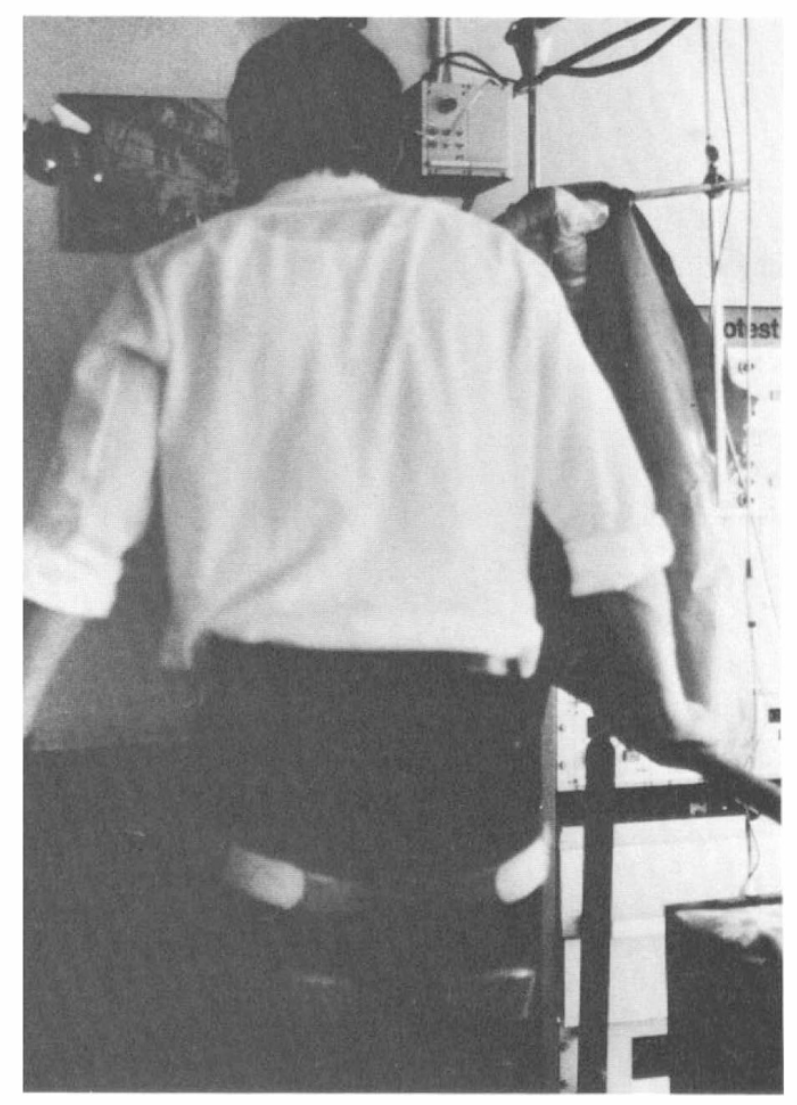

FIG. I

Patient with long leg braces ambulating on the treadmill, breathing into the Douglas bag. 
TABLE II

Cardio-pulmonary behaviour during walking between the parallel bars

\begin{tabular}{|c|c|c|c|c|c|c|}
\hline Subjects & $\begin{array}{c}\text { Speed } \\
\left(\mathrm{m} / \mathrm{min}^{-1}\right)\end{array}$ & $\begin{array}{c}\text { H.R. } \\
\left(\mathrm{n} / \min ^{-1}\right)\end{array}$ & $\begin{array}{c}\text { Ventilation } \\
\mathrm{L}_{\mathrm{BTPS} \text { min }}\end{array}$ & \multicolumn{3}{|c|}{$\mathrm{O}_{2}$ consumption $\left(\right.$ in $\mathrm{mlO}_{2}$ ) } \\
\hline I U.A.P. & 8 & 130 & $30 \cdot 5$ & 945 & I 5.5 & I $\cdot 93$ \\
\hline 2 U.A.P. & 7 & 130 & 23.5 & 855 & I I 2 & 1.60 \\
\hline 3 U.A.P. & IO & I 45 & $30 \cdot 0$ & 870 & I $2 \cdot 2$ & $\mathrm{I} \cdot 22$ \\
\hline 4 U.A.P. & IO & 120 & I 5.9 & 788 & I I $\cdot \mathbf{I}$ & I $\cdot$ I I \\
\hline $\bar{M}$ & $8 \cdot 75$ & I3 I & $25 \cdot 0$ & 864 & I 2.5 & I. 46 \\
\hline 5 A.P. & I 6 & I 45 & I 4.4 & 637 & $9 \cdot 5$ & 0.59 \\
\hline 6 A.P. & I 6 & I 38 & I9.3 & 824 & $8 \cdot 2$ & 0.63 \\
\hline 7 A.P. & I 6 & I 40 & $16 \cdot 5$ & 712 & $9 \cdot 6$ & 0.60 \\
\hline $\bar{M}$ & I 5 & I 4 I & I6.7 & 724 & $9 \cdot I$ & $0.6 I$ \\
\hline $8 \mathrm{~N}$ & IO & 105 & $25 \cdot 0$ & 860 & I I 8 & $\mathrm{I} \cdot \mathrm{I} 8$ \\
\hline $9 \mathrm{~N}$ & I 5 & 105 & $24 \cdot 0$ & 790 & 10.5 & 0.70 \\
\hline IO N & IO & 90 & $17 \cdot 5$ & 510 & $10 \cdot 6$ & I.06 \\
\hline I I $\mathrm{N}$ & 20 & 80 & I $8 \cdot 5$ & 913 & $12 \cdot 7$ & 0.63 \\
\hline I2 N & 20 & 90 & $16 \cdot 6$ & 810 & I I 5 & 0.57 \\
\hline $\bar{M}$ & 15 & 94 & $20 \cdot 3$ & 776 & $11 \cdot 4$ & 0.83 \\
\hline
\end{tabular}

exact data for each subject can be found in the various tables. Before this experiment none of the subjects had ever walked on a treadmill. Therefore any possible variations in oxygen uptake due to learning to ambulate in a treadmill were considered negligible, since all subjects were in the same situation.

Secondly, the three A.P.s, one of the U.A.P.s and two subjects of the normal group performed pendular walking on a flat floor using two Lofstrand type canes (Fig. 2). This evaluation was made under actual daily life conditions.

During the walking exercises oxygen consumption was calculated in an open circuit using measurements of ventilation and the analysis of expired gas. With the use of a mouthpiece and directional valves having a weak resistance, the subject inspired atmospheric air and expired into a Douglas bag. The volume of the expired gas was measured in a Tissot bell with a precision of $50 \mathrm{ml}$. After the absorption of water vapour the $\mathrm{CO}_{2}$ and $\mathrm{O}_{2}$ concentration were determined by physical methods (Jager). A continuous electrocardiograph recorded by telemetry permitted a calculation of the heart rate (Dannika). The reproducibility of the basic experimental design is excellent and estimated at $2 \cdot 4$ per cent.

\section{Results}

The results of the cardiopulmonary measurements during ambulating between parallel bars are shown in Table II.

Since pendular walking involves a displacement of body weight the consumption of oxygen evaluated in $\mathrm{ml} / \mathrm{min}$ was also expressed in $\mathrm{kg}$ of body weight, as well as $\mathrm{ml}$ of $\mathrm{O}_{2}$ per body weight for the distance in metres that was walked $\left(\mathrm{ml} \mathrm{O}_{2} / \mathrm{kg} / \mathrm{m}\right)$. During this exercise between the parallel bars the mean pendular walking speed of the unaccustomed paraplegic 


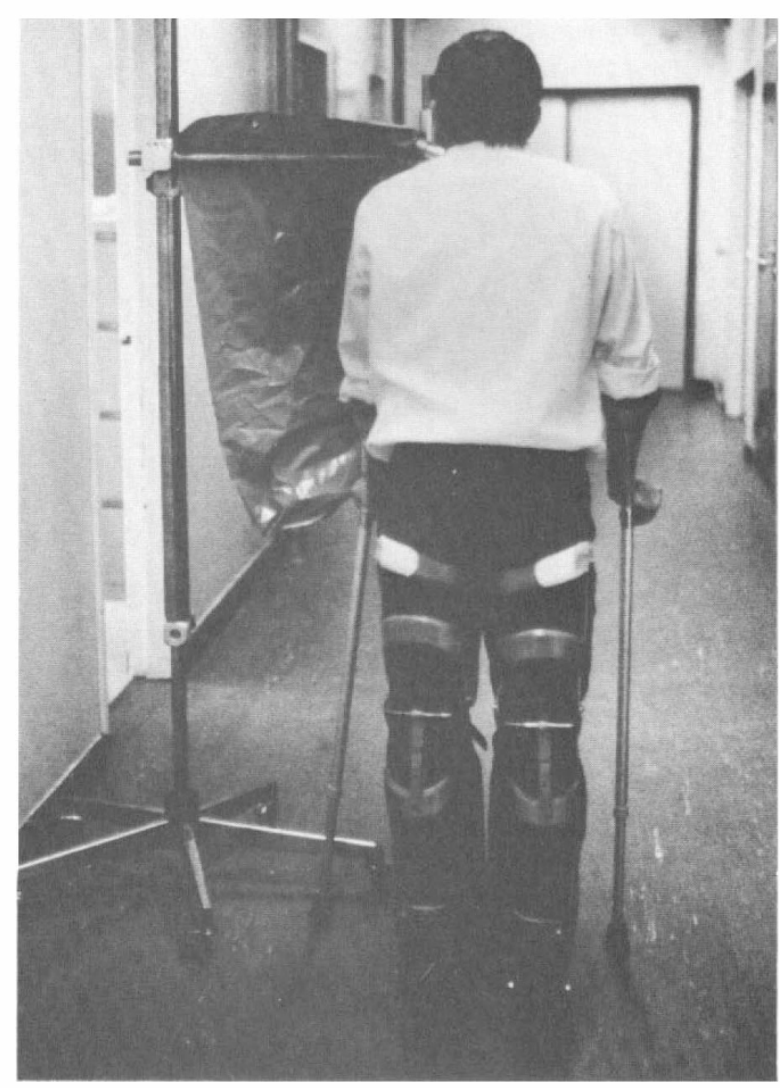

FIG. 2

Patient attached to the Douglas bag (pushed by an assistant) walking on a flat floor.

group could be estimated at 8.75 metres per minute with an average cardiac rate of $\mathrm{I} 3 \mathrm{I} / \mathrm{min}$. Ventilation was relatively high at $25 \mathrm{l} / \mathrm{min}$ and was accompanied by an oxygen consumption of $864 \mathrm{ml} / \mathrm{min}$.

Therefore, the oxygen consumption related to each $\mathrm{kg}$ of body weight was $\mathrm{I} 2.5 \mathrm{ml} \mathrm{O} / 2 \mathrm{~min}$ and $\mathrm{I} \cdot 46 \mathrm{ml} \mathrm{O} / 2 \mathrm{~kg}$ for each metre walked.

In the second group of paraplegics accustomed to walking with long leg braces the displacement was I 5 metres a minute and the heart rate was I $4 \mathrm{I} / \mathrm{min}$. On the other hand the ventilation was lower at $\mathrm{I} 6.7 \mathrm{l} / \mathrm{min}$ and, above all, the $\mathrm{O}_{2}$ consumption $/ \mathrm{min} / \mathrm{kg}$ decreased to $9 \cdot \mathrm{I} \mathrm{ml}$. This difference is even more pronounced if the distance travelled is taken into consideration: the average consumption of $\mathrm{O}_{2}$ is $0.6 \mathrm{I} \mathrm{ml} / \mathrm{kg} / \mathrm{m}$.

The control group of subjects walked at an average of 15 metres a minute with a relatively low heart rate of $94 / \mathrm{min}$, an average ventilation of $20.3 \mathrm{l} / \mathrm{min}$ and a mean consumption of $\mathrm{O}_{2}$ of I I $\cdot 4 \mathrm{~m} / \mathrm{min} / \mathrm{kg}$ which corresponds to $0.83 \mathrm{ml}$ of $\mathrm{O}_{2} / \mathrm{kg} / \mathrm{m}$.

Table III gives an overall summary of our observations on subjects who walked using canes on a flat floor. All our patients did not participate in this experience but one of the U.A.P.s only travelled the short distance of 4 metres a minute with an $\mathrm{O}_{2}$ consumption of $12.9 \mathrm{ml} / \mathrm{min} / \mathrm{kg}$. If the 
TABLE III

Cardio-pulmonary behaviour during walking with crutches

\begin{tabular}{|c|c|c|c|c|c|c|}
\hline Subjects & $\begin{array}{c}\text { Speed } \\
\left(\mathrm{m} / \mathrm{min}^{-1}\right)\end{array}$ & $\begin{array}{c}\text { H.R. } \\
\left(\mathrm{n} / \mathrm{min}^{-1}\right)\end{array}$ & $\begin{array}{c}\text { Ventilation } \\
\mathrm{L}_{\mathrm{BTPS} / \text { min }}\end{array}$ & $\begin{array}{l}\mathrm{O}_{2} \mathrm{co} \\
\mathrm{min}^{-1}\end{array}$ & $\begin{array}{l}\text { sumption (i } \\
\mathrm{min}^{-1} / \mathrm{kg}^{-1}\end{array}$ & $\begin{array}{l}\left.\mathrm{ml} \mathrm{O}_{2}\right) \\
\mathrm{kg}^{-1} / \mathrm{m}^{-1}\end{array}$ \\
\hline 4 U.A.P. & 4 & I I 5 & $23 \cdot I$ & 920 & $12 \cdot 9$ & $3 \cdot 25$ \\
\hline $\begin{array}{c}5 \text { A.P. } \\
6 \text { A.P. } \\
7 \text { A.P. } \\
\bar{M}\end{array}$ & $\begin{array}{l}23 \\
21 \\
24 \\
22.6\end{array}$ & $\begin{array}{l}160 \\
162 \\
148 \\
156\end{array}$ & $\begin{array}{l}3 I \cdot 2 \\
29 \cdot 4 \\
25 \cdot I \\
28 \cdot 8\end{array}$ & $\begin{array}{l}\text { I } 106 \\
1305 \\
\text { I } 234 \\
\text { I } 215\end{array}$ & $\begin{array}{l}16.5 \\
\text { I } 6.3 \\
\text { I } 6.6 \\
\text { I } 6.5\end{array}$ & $\begin{array}{l}0.72 \\
0.77 \\
0.69 \\
0.73\end{array}$ \\
\hline $\begin{array}{c}\text { I I } \mathrm{N} \\
\text { I } 2 \mathrm{~N} \\
\bar{M}\end{array}$ & $\begin{array}{l}26 \\
35 \\
30 \cdot 5\end{array}$ & $\begin{array}{r}95 \\
115 \\
105\end{array}$ & $\begin{array}{l}19 \cdot 5 \\
24 \cdot I \\
2 I \cdot 8\end{array}$ & $\begin{array}{r}859 \\
1217 \\
1038\end{array}$ & $\begin{array}{l}\text { I I } 9 \\
\text { I } 5.9 \\
\text { I } 3.9\end{array}$ & $\begin{array}{l}0.46 \\
0.45 \\
0.455\end{array}$ \\
\hline
\end{tabular}

energy used per metre is considered the high figure of $3.25 \mathrm{ml}$ of $\mathrm{O}_{2} / \mathrm{kg} / \mathrm{m}$ is obtained. The group of A.P.s had a relatively high consumption of $\mathrm{O}_{2}$ at $16.5 \mathrm{ml} / \mathrm{min}$ as well as a marked increase of the heart rate to $156 / \mathrm{min}$.

In addition, the ventilation was at the high level of $28.8 \mathrm{l} / \mathrm{min}$. Nevertheless the walking speed was $22.6 \mathrm{~m} / \mathrm{min}$ and the relative energy utilisation was $0.73 \mathrm{ml}$ of $\mathrm{O}_{2} \mathrm{~kg} / \mathrm{m}$.

The control subjects covered an average distance of $30.5 \mathrm{metres} / \mathrm{min}$ by the same method of walking with a heart rate of $105 / \mathrm{min}$, an energy utilisation of $0.455 \mathrm{ml}$ of $\mathrm{O}_{2} \mathrm{~kg} / \mathrm{min}$.

\section{Discussion}

Experience has shown, and certain authors have also observed (Rosman and Spira, 1974), that only a minority of patients having a complete medullary lesion use the walking splint that was prescribed. Only those with a good motivation and a low lesion, between TIO and LI, wear their appliances regularly. Walking with this type of orthosis, which weighs between 4 and $8 \mathrm{~kg}$ depending on whether it is made of an aluminium alloy or steel, requires an energy consumption which is much greater than that used to travel in a wheel chair or that used by other handicapped persons with motor lesions or, of course, by that of normal walking (Fisher and Gullickson, 1978). The results that we obtained in our paraplegic patients also show that the energy consumption used in walking is clearly increased compared to normal individuals. Nevertheless, a difference must be made between the unaccustomed paraplegic and those that utilise their appliances regularly after 4 or 5 years of paraplegia. In fact, in the U.A.P. group, the speed of walking on a treadmill is very slow with an energy output that is much higher than the other groups. The first part of our study shows that swing-through walking between parallel bars involves energy consumption per metre travelled which is clearly higher in U.A.P.s than in A.P.s. Moreover, these accustomed paraplegics had an oxygen consumption lower than normal control subjects performing the same exercise. In addition, the walking speed of A.P.s is double that of U.A.P.s with a lower ventilation and a clearly lower consumption of oxygen. This investigation also shows that the swing-through gait in the paraplegic requires a greater overload on the cardiovascular system than on the ventilatory function. 
Clinkingbeard et al. (I964) studied two groups of paraplegics during their rehabilitation (over a period of I 8 months). Two of the paraplegics with a lesion at $\mathrm{T}_{4}$ walked at the same slow speed as that of our unaccustomed patients with a high oxygen consumption.

Moreover, three paraplegics with lower lesions $\left(\mathrm{L}_{\mathrm{I}}\right)$ walked at the same rate as our accustomed patients. This exercise involved a walking speed five times faster than the patients with high lesions with a net decrease (of about 25 per cent), in the oxygen consumption per kilo and per metre. We experienced approximately the same difference between our U.A.P. and our A.P.s while walking with crutches under every-day conditions. The A.P.s walk at a speed five times faster than the unaccustomed patient with a consumption of $\mathrm{O}_{2} / \mathrm{kg} / \mathrm{m}$, almost five times less (Table III). If there is evidently a significant difference favouring the accustomed paraplegics compared to the unaccustomed patient they did not however, equal the healthy subject's economic consumption of oxygen per kilo and per metre. It is difficult to compare our study with those obtained by other authors, e.g. Ragnarsson et al. (1975), who did not use the same parameters and did not evaluate their results per kilo of body weight. In addition, the patients in some studies were not investigated under the same conditions; certain patients used pneumatic appliances which were distinctly less heavy (average of $2.6 \mathrm{~kg}$ ) while others used a metal apparatus and in some cases they walked with canes aided by other persons. On the other hand the study of Huang et al. (1979) is closer to ours even though their eight patients were all subjects accustomed to brace use and were observed at a precise time in their evolution, i.e. several months after their rehabilitation. The way of walking, however, was not similar: their patients used a walking platform instead of canes, which gave them a walking speed that was much slower than that of our accustomed paraplegics.

The patients of Huang had a consumption of oxygen during walking three times greater than when they were at rest. The consumption of oxygen during the walk was $892 \mathrm{ml} \mathrm{O}_{2} /$ min for the patients with high lesions ( $\mathrm{T}_{4}$ ) and $1052 \mathrm{ml} \mathrm{O}_{2} / \mathrm{min}$ for the subjects with a low lesion (TII-TI2). Therefore, our only unaccustomed paraplegic had an $\mathrm{O}_{2}$ consumption $(920 \mathrm{ml}$ $\mathrm{O}_{2} / \mathrm{min}$ ) closer to the patients with a high lesion in Huang's study (I979), while the group of accustomed patients had an $\mathrm{O}_{2}$ consumption of $\mathrm{I} \cdot 2 \mathrm{I} 5$ $\mathrm{ml} \mathrm{O}_{2} / \mathrm{min}$. These values of our patients also represent a little more than three times their $\mathrm{O}_{2}$ consumption evaluated at rest (Table IV).

\section{Conclusion}

Although the bilateral long leg braces are used by a minority of people with complete paraplegia, we were able to show during this study that the paraplegic unaccustomed to wearing long-leg braces (or with a high level lesion), has a slower swing-through walking speed in order to decrease energy expenditure. Even though the U.A.P. has a much higher oxygen consumption $/ \mathrm{kg} / \mathrm{m}$, either on the treadmill or in an everyday situation on a flat floor than the A.P., the latters performance is much better and approaches closely that of a normal person when he is forced to walk with the same swing-through gait. This high energy cost could be explained by the increased work of the upper musculature which not only must perform motor work but must also maintain a precarious balance. In addition, 
TABLE IV

Mean result at rest

\begin{tabular}{lcccc}
\hline Subjects & $\begin{array}{c}\text { Weight } \\
(\mathrm{kg})\end{array}$ & $\begin{array}{c}\mathrm{H} . \mathrm{R} . \\
(\mathrm{m} / \mathrm{min})\end{array}$ & $\begin{array}{c}\mathrm{O}_{2} \text { Consumption } \mathrm{ml} \mathrm{O}_{2} / \mathrm{min} \mathrm{kg} \\
\mathrm{ml} \mathrm{O}_{2} / \mathrm{min}\end{array}$ \\
\hline I U.A.P. & $\mathrm{m}: 70$ & 86 & 305 & 4.2 \\
3 A.P. & $\mathrm{m}: 74$ & 88 & 340 & 4.6 \\
2 N & $\mathrm{m}: 7 \mathrm{I}$ & 62 & 267 & 3.7 \\
\hline
\end{tabular}

spasticity should not be forgotten since it certainly plays a role in the increased metabolic costs.

This study has demonstrated that, when paraplegics are allowed to ambulate at a comfortable speed which they themselves dictate, energy consumption is inversely related to the regular use of long leg braces and directly related to the level of spinal lesion. The inverse was true concerning gait velocity, which was directly related to brace use and inversely related to the level of the lesion.

Therefore, the regular utilisation at medium and long term, of bilateral long leg braces provides the paraplegic with a much greater efficiency of energy utilisation, as evidence by the significantly lower $\mathrm{O}_{2}$ consumption/ $\mathrm{kg} / \mathrm{m}$. This suggests a more efficient mechanical utilisation of energy, but perhaps also, an adaptation of muscle metabolism and, in particular, the induction of oxydative enzymes.

However, this type of walking still involves an important cardiovascular effort and to a lesser degree an increase of ventilatory functions.

\section{RÉSUMÉ}

Le coût énergétique de la marche avec appareillage a été apprécié chez 7 patients masculins paraplégiques présentant une lésion médullaire complète ( $\mathrm{D}_{9}$ à $\left.\mathrm{L}_{\mathrm{I}}\right)$.

Quatre d'entre eux peuvent être considérés comme non entraînés et les trois autres utilisent régulièrement leur appareillage depuis plus de 4 ans. Cinq sujets normaux réalisent le même protocole à titre témoin. Tous les sujets ont été soumis à une épreuve de marche sur tapis roulant avec appui des mains sur des barres parallèles. Certains d'entre eux réalisent un déplacement sur un sol plat avec l'aide de cannes dans un deuxième essai.

Lors de la première épreuve, la consommation d' $\mathrm{O}_{2}$ est de $\mathrm{I}, 46 \mathrm{ml} \mathrm{O} / 2 / \mathrm{kg} / \mathrm{m}$ pour les paraplégiques non entraînés, de $0,6 \mathrm{I} \mathrm{ml} \mathrm{O} / \mathrm{kg} / \mathrm{m}$ pour les paraplégiques entraînés et de $0,83 \mathrm{ml} \mathrm{O}_{2} / \mathrm{kg} / \mathrm{m}$ pour la population témoin.

Dans les conditions réelles de marche, la consommation $\mathrm{d}^{\prime} \mathrm{O}_{2}$ pour les paraplégiques entraînés est de $0,73 \mathrm{ml} \mathrm{O}_{2} / \mathrm{kg} / \mathrm{m}$ et s'accompagne d'une sollicitation cardiaque importante (FC à $156 / \mathrm{min}$ ). La consommation d' $\mathrm{O}_{2}$ ainsi obtenue est beaucoup plus faible que la valeur de $3,25 \mathrm{O}_{2} / \mathrm{kg} / \mathrm{m}$ mesurée chez le sujet non entraîné et est un peu plus élevée que la valeur de $0,45 \mathrm{ml} \mathrm{O} / \mathrm{kg} / \mathrm{m}$ de la population témoin.

\section{ZUSAMMENFASSUNG}

Der Energieverbrauch der Fortbewegung mit Hilfe eines Gehapparates wurde bei 7 männlichen Paraplegikern, welche eine komplette Rückenmarksläsion (zwischen $\mathrm{D}_{9}$ und $\mathrm{LI}_{\mathrm{I}}$ ) aufweisen, gemessen. Vier unter ihnen können als körperlich nicht trainiert angesehen werdren, die drei übrigen verwenden ihren Gehapparat regelmässig seit mehr als vier Jahren. Eine Vergleichsgruppe von fünf gesunden Personen wurde demselben Untersuchungsprotokoll unterworfen. Alle führten einen Gehbelastungstest auf einem Rollteppich mit Aufstützmöglichkeit auf zwei Parallelbarren durch. Einige von ihnen bewegten sich auf ebenem Boden unter Zuhilfenahme von Stützkrücken. 
Der während des ersten Testes gemessene Sauerstoffverbrauch is $\mathrm{I}, 46 \mathrm{ml} \mathrm{O} / \mathrm{kg} / \mathrm{m}$ bei den untrainierten Paraplegikern, $0,6 \mathrm{I} \mathrm{ml} \mathrm{O}_{2} / \mathrm{kg} / \mathrm{m}$ bei den trainierten Patienten und 0,83 $\mathrm{ml} \mathrm{O}_{2} / \mathrm{kg} / \mathrm{m}$ bei der Kontrollgruppe.

Während normaler Bedingungen der Fortbewegung ist der Sauerstoffverbrauch der trainierten Paraplegiker $0,73 \mathrm{ml} \mathrm{O}_{2} / \mathrm{kg} / \mathrm{m}$, er ist mit einer beträchtlichen Herzbelastung (Pulsfrequenz von I56/min) verbunden. Der so festgestellte Sauerstoffverbrauch ist wesentlich geringer als die $3,25 \mathrm{ml} \mathrm{O} / \mathrm{kg} / \mathrm{m}$, die man bei nicht trainierten Patienten messen kann und nur wenig höher als der bei der Kontrollgruppe gemessene Wert von $0.45 \mathrm{ml}$ $\mathrm{O}_{2} / \mathrm{kg} / \mathrm{m}$.

\section{REFERENCES}

BARD, B. (1963). Energy expenditure of hemiplegic subjects during walking. Arch. phys. Med. Rehabil., 44, 368-370.

Chantraine, A. \& Onkelinx, A. (1975). Analysis of compensatory muscles during walking in paraplegic patients. Scand. F. Rehab. Med., 7, 9-I 2.

Clinkingbeard, J. R., Gersten, J. W. \& Hoehn, D. (i 964). Energy cost of ambulation in traumatic paraplegic. Am. F. Phys. Med., 43, I 57-I65.

Fisher, S. V. \& GUllickson, G. ( I 978). Energy cost of ambulation in Health and Disability: A literature Review. Arch. Phys. Med. Rehabil., 59, I 24-I 33.

Ganguli, S., Datta, S. R., Chatterjee, B. B. et al. (I973). Performance evaluation of amputee-prosthesis system in below-knee amputees. Ergonomics, 16, 797-810.

Ganguli, S., Bose, K. S., Datta, S. R. et al. (1974). Ergonomics evaluation of above-knee amputee-prosthesis combinations. Ergonomics, I7, I99-2I0.

Huang, C. T., Kuhlemeier, K. V., Moore, N. B. \& Fine, P. R. ( I979). Energy cost of ambulation in paraplegic patients using craigscott braces. Arch. phys. Med. Rehabil., 6o, 595-600.

Imms, E. J., Macdonald, I. C. \& Prestidge, S. P. (i976). Energy expenditure during walking in patients recovering from fractures of the leg. Scand. $尹$. Rehab. Med., 8, I-9.

JAMES, U. (I973). Oxygen uptake and heart rate during prosthetic walking in healthy male unilateral above-knee amputees. Scand. F. Rehabil. Med., 5, 71-80.

Ragnarsson, K. T., Sell, G. H., McGarrity, M. \& Ofir, R. (I975). Pneumatic orthosis for paraplegic patients: functional evaluation and prescription considerations. Arch. Phys. Med. Rehabil., 56, 479-483.

Rosman, N. \& Spira, E. (I974). Paraplegic use of walking braces: survey. Arch. Phys. Med. Rehabil., 55, 310-3 I4.

Salmon, A. \& Chantraine, A. (I972). Le coût énergétique de la déambulation chez le paraplégique appareillé. 6éme Congrès inter. de Méd. Phys., 2, 769-773.

Veicsteinas, A., Aghemo, P., Margaria, R., Cova, P. \& Pozzolini, M. (i979). Energy cost of walking with lesions of the foot. The fournal of Bone and Foint Surgery, 6r A, 7, $1073-1076$. 